\title{
Metallothionein mRNA Sequencing and Induction by Cadmium in Gills of the Crucian Carp, Carassius auratus
}

\author{
Heekyung Bae, ${ }^{a}$ Seong Sook Nam, ${ }^{b}$ Hyoung-Sook Park, ${ }^{c}$ and Kwangsik Park ${ }^{*}, d$ \\ ${ }^{a}$ Risk Research Department, National Institute of Environmental Research, Gyeongseo-dong, Seo-gu, Incheon 404-170, Korea, ${ }^{b} Y o n s e i$ \\ University, 234 Maeji-ri, Hungeob-myon, Wonju-si, Gangwon-do 220-710, Korea, 'Department of Environmental Engineering, Hanseo \\ University, 360 Daegokyi, Haemimyun, Seosanshi, Chungnam 356-706, Korea, and ${ }^{d}$ College of Pharmacy, Dongduk Women's Uni- \\ versity, 23-1 Wolgok-dong, Seongbuk-gu, Seoul 136-714, Korea
}

(Received August 27, 2004; Accepted January 7, 2005)

\begin{abstract}
Metallothioneins (MTs) are inducible metal-binding proteins characterized by low molecular weight (6000$10000 \mathrm{Da}$ ) and play a major role in detoxification of heavy metals. They are known to be induced by heavy metals in various organs of different species and represent a potential biomarker of aquatic contamination with heavy metals. In this study, cloning and sequencing of a MT gene of the Korean freshwater fish, the crucian carp (Carassius auratus), were performed. Furthermore, the gene expression and cadmium accumulation in the gills of the crucian carp were compared during the cadmium exposure period of 25 days. The MT gene, lacking the $5^{\prime}$ promoter region, is $405 \mathrm{bp}$ long and has a tripartite structure consisting of three exons and two introns. The open reading frame encodes a cysteine-rich ( 20 cysteines) polypeptide of 60 amino acids containing six Cys-X-Cys motifs, typically found in this protein family. It was found that the expression of MT mRNA of gills was very low in normal control fish but high mRNA expression was induced after 1-day exposure to cadmium. However, the mRNA levels decreased after 1 day even though the cumulative cadmium concentration increased during the remaining exposure period. These results suggest that MT expression does not always reflect the cadmium accumulation in the gills of the fish and may have limitations in its use as a biomarker to monitor cadmium contamination of aquatic environments.
\end{abstract}

Key words — Carassius auratus, metallothionein gene expression, cadmium

\section{INTRODUCTION}

In terms of protein metabolism induced by heavy metals, metallothioneins (MTs) are the most widely studied proteins. They are characterized by low molecular weight, high cysteine content, lack of aromatic amino acids, and ability to bind heavy metals such as cadmium, zinc, and copper via mercaptide linkages. MTs have been postulated to play a role in the detoxification of heavy metals, homeostasis of copper and zinc, and protection against reactive oxygen species. ${ }^{1-3)}$ In a study using genetically produced mutant mice, it was revealed that MTs are not essential for development but they protect against heavy metal toxicity. ${ }^{4}$ It was also observed that the

*To whom correspondence should be addressed: College of Pharmacy, Dongduk Women's University, 23-1 Wolgok-dong, Seongbuk-gu, Seoul 136-714, Korea. Tel.: +82-2-940-4522; Fax: +82-2-940-4195; E-mail: kspark@ dongduk.ac.kr synthesis of MT is regulated by a transcriptional process by metals. ${ }^{5,6}$ Currently, there is much interest in molecular biomarkers for the monitoring of environmental contamination using MT. ${ }^{7,8)}$ In this study, the sequences of MT cDNA and genomic DNA of crucian carp, which are widely distributed in Korean freshwater, were analyzed. Furthermore, measurement of gene expression and cadmium accumulation in the gills was also investigated to evaluate biomonitoring assays using molecular markers with reverse-transcription (RT)-PCR based on the identified cDNA sequences.

\section{MATERIALS AND METHODS}

Fish and Cadmium Exposure - The crucian carp (Carassius auratus, C. auratus) used in this study were supplied by the Inland Fisheries Ecological Research Institute (Cheongpyeong, Korea) and 
were maintained at the Environmental Toxicology Laboratory, National Institute of Environmental Research (Incheon, Korea). They were kept in $50 \times 35$ $\times 32 \mathrm{~cm}$ water tanks at $25 \pm 1{ }^{\circ} \mathrm{C}$ on $16-\mathrm{hr}$ light $/ 8$-hr dark cycle $(\mathrm{pH} 7.0 \pm 0.2$; dissolved oxygen $7.5 \pm$ $0.5 \mathrm{mg} / \mathrm{l})$. Fish were fed once daily during experiments. Forty-eight fish weighing around $28-60 \mathrm{~g}$ were selected and divided into groups for cadmium exposure at concentrations of $0.01,0.1$, and $0.5 \mathrm{mg} / \mathrm{l}$ for 25 days and killed on day 1 , day 5 , day 15 , and day 25 , respectively. The cadmium concentrations used in this study were considered nominal concentrations, and fish were maintained in semi-static conditions renewed three times a week.

PCR Primers for Sequencing of the MT Gene of C. auratus — The primers for the cloning and sequencing of MT cDNA of $C$. auratus were designed on the basis of those for goldfish. The primers were: MT-A, 5'-CAGTGTACAACCTGCAAGAA-3' (F, forward) and 5'-CAGGGAGGTCGTTTATTAGA-3' (R, reverse); MT-B, 5'-ATGGATCCCTGCGATTGC-3' (F) and 5'-AGAAGAACAGGGAGGTCGT-3' (R). For the $3^{\prime}$-rapid amplification of $3^{\prime}$-cDNA ends ( $3^{\prime}$-RACE), the oligo-dT adapter primer (AP, 5'-GGCCACGCGTCGACTAGTACTTTTTTTTTTTTTTTTT-3'); MT-B(F), 5' ATGGATCCCTGCGATTGC- $3^{\prime}$, and Abridged Universal Amplification Primer (AUAP, 5'-GGCCACGCGTCGACTAGTAC- $3^{\prime}$ ) were used. $\beta$-actin was used as a housekeeping gene to normalize mRNA levels, and the primers were synthesized as follows: $\beta$-actin-F, 5'-TTCAACAGCCCTGCCATGTA-3' (F); $\beta$-actin-R; $5^{\prime}$-ATACCGCAGGACTCCATACCAA-3' (R).

Preparation of Genomic DNA and Total RNA Genomic DNA(gDNA) and total RNA were carefully extracted from approximately $50 \mathrm{mg}$ of liver tissue of crucian carp for MT gene sequencing. For the preparation of gDNA and total RNA, a DNA extraction kit (Amersham Pharmacia, Piscataway, NJ, U.S.A.) and a RNAgent Total RNA Isolation System (Promega, Madison, WI, U.S.A.) were used according to the manufacturer's instructions, respectively. Total RNA concentration was determined by absorbance at $260 \mathrm{~nm}$ and purity was determined by the $260 / 280 \mathrm{~nm}$ absorption ratio. The purity of prepared total RNA was examined by agarose gel electrophoresis (data not shown). There was little or no degradation in the preparations as judged by the integrity of the $18 \mathrm{~S}$ and $28 \mathrm{~S}$ rRNA bands. Purified RNA samples were diluted at $1 \mu \mathrm{g} / \mu$ l for RT-PCR and store at $-80^{\circ} \mathrm{C}$ until further use. The details were described in previous reports. ${ }^{9,10)}$

\section{Cloning and Sequencing of MT gDNA and cDNA}

of $\boldsymbol{C}$. auratus — For the sequence analysis of MT gDNA, PCR amplification of gDNA using several pairs of primers was performed in a $20 \mu$ l total mixture volume for 25 cycles of $95^{\circ} \mathrm{C}$ for $1 \mathrm{~min}$, $55^{\circ} \mathrm{C}$ for $1 \mathrm{~min}$, and $72^{\circ} \mathrm{C}$ for $1 \mathrm{~min}$. The PCR reaction contained $1 \mu \mathrm{g}$ of $\mathrm{gDNA}, 2 \mu \mathrm{l}$ of $20 \mathrm{uM}$ primer, and $17 \mu \mathrm{l}$ of reaction mixture provided from a product of Bioneer, AccuPower PCR PreMix (Bioneer, Daejeon, Korea). For the sequence analysis of MT gDNA, the amplified PCR products were gel purified using the Matrix Gel extraction kit according to the manufacturer's instruction (Gibco BRL, CA, U.S.A.), ligated into the pGEM-T easy vector (Promega), and then the gDNA clones were applied to an automatic DNA sequencer (ABI 3700, Applied Biosystems, Foster City, CA, U.S.A.).

For the analysis of cDNA sequence, rapid amplification of 3' cDNA ends was carried out with RNA. In brief, RT PCR was performed using oligo deoxythymidine primer in $20-\mu \mathrm{l}$ volumes at $55^{\circ} \mathrm{C}$ for $30 \mathrm{~min}$. The RT-PCR reaction contained $1 \mu \mathrm{g}$ of total RNA, $1 \mu \mathrm{l}$ of 20 -uM oligo dT primer, and $18 \mu \mathrm{l}$ of reaction mixture provided from a product of Bioneer, AccuPower RT/PCR PreMix (Bioneer). Then PCR was performed in a $20-\mu$ l total mixture volume for 25 cycles of $95^{\circ} \mathrm{C}$ for $1 \mathrm{~min}, 55^{\circ} \mathrm{C}$ for $1 \mathrm{~min}$, and $72^{\circ} \mathrm{C}$ for $1 \mathrm{~min}$. The PCR reaction contained $2 \mu \mathrm{l}$ of the RT reaction mixture as a cDNA template, $2 \mu$ l of 20 -uM primer, and the reaction mixture described above. Amplified cDNA products for the MT mRNA of crucian carp were separated on $1 \%$ agarose gel by electrophoresis. Sequence analysis of MT cDNA was carried out using the same process described above in the gDNA sequence analysis and described in a previous report. ${ }^{11)}$

Expression of MT mRNA — — For the analysis of MT mRNA expression in the gills, total RNA was isolated from the crucian carp exposed to cadmium at different concentrations and amplified using the RT-PCR method described above. PCR primers for the MT mRNA expression were MT-A (F, R). Each PCR product was resolved on $1 \%$ agarose gel, photographed, and analyzed using image analysis (Kodak Digital Science, U.S.A.). Detailed methods of mRNA expression were described in a previous report. ${ }^{12)}$

Cadmium Analysis in Tissues — To compare the MT mRNA induction and cadmium accumulation in tissue, the concentrations in gills were analyzed as described by Barak and Mason, ${ }^{13)}$ using an 
acidic analysis method. About 300-500 mg samples of frozen tissues were transferred into flasks and $4 \mathrm{ml}$ of acidic solution $\left(\mathrm{HNO}_{3}: \mathrm{HClO}_{4}=4: 1\right)$ were added to the samples. The samples were heated at $40^{\circ} \mathrm{C}$ for $1 \mathrm{hr}$ and then continued heating at $140^{\circ} \mathrm{C}$ for $90 \mathrm{~min}$. After cooling, the digestion products were transferred to $10 \mathrm{ml}$ volumetric flasks and diluted to $10 \mathrm{ml}$ with deionized water. The cadmium concentrations were determined using an atomic absorption spectrophotometer (SPECTR 880, Varian, Melbourne, Australia). Three tissue samples from the individual fish in each group were analyzed for cadmium accumulation in the gills.

\section{RESULTS AND DISCUSSION}

\section{Sequence of MT gDNA and cDNA}

The presence of MT has been known and characterized in numerous fish including trout, ${ }^{14)}$ goldfish ${ }^{15)}$ flounder, ${ }^{16)}$ carp, ${ }^{17)}$ and Japanese crucian carp. ${ }^{18,19)}$ As with many other vertebrate species, resistance to heavy metal toxicity in fish is related to their ability to overexpress MT genes after exposure to metal ions. ${ }^{20)}$

In this study, sequencing and expression of MT mRNA in the Korean freshwater fish C. auratus were studied. Several primers were synthesized based on the known gold fish cDNA sequences from GenBank (accession number: S75039) ${ }^{15)}$ for amplification and cloning of the MT gene of $C$. auratus. Among them, two pairs of primers (MT-A, MT-B) worked well for the amplification of cDNA and gDNA (Fig. 1). cDNA fragments in lanes 1 and 3 in Fig. 1 were amplified by MT-A (F, R) and MT-B (F, R), respectively, and were shown to be about 250 and 300 basepairs (bp) on the 1\% agarose gel. Lane 2 and 4 show the gDNA fragments amplified by MT-A (F, $\mathrm{R})$ and MT-B (F, R) and the molecular sizes were about 300 and $450 \mathrm{bp}$, respectively.

From the results of sequence analysis, all the PCR products were found to have identical sequences. The amplified PCR products in lanes 1 and 2 in Fig. 1 were identified as a part of MT cDNA and MT gDNA, respectively. The amplified PCR products in lanes 3 and 4 covered the full sequence of MT cDNA and MT gDNA, respectively. Lane 5 in Fig. 1 shows the product of $3^{\prime}$-RACE of MT cDNA using the primers of MT-B (F) and AUAP. 3'-RACE takes advantage of the natural poly(A) tail found in mRNA as a generic priming site for PCR. mRNA was converted into MT cDNA using the RT

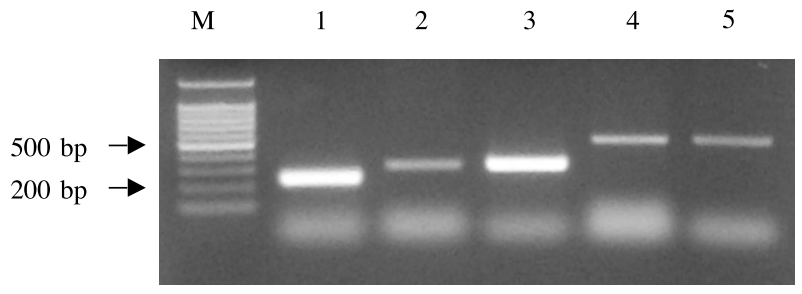

Fig. 1. RT-PCR Products of MT from the Gills of $C$. auratus Amplified cDNA and gDNA products with different primers are shown on the agarose gel. Lane 1, cDNA product amplified by primers of MT-A (F, R); lane 2, gDNA product amplified by MT-A (F, R); lane 3, cDNA product amplified by primers of MT-B (F, R); lane 4, gDNA product amplified by MT-B (F, R); lane 5, 3'-RACE product amplified by MT-B (F) and AUAP. Lane M represents the molecular size markers.

and oligo-dT AP. MT cDNA is then amplified by PCR using the MT-B (F) primer that anneals to a region of exon sequences and AUAP primer that targets the poly(A) tail region.

Figure 2A shows the MT gDNA sequence and the structure of this gene. The sequence analysis of gDNA revealed $405 \mathrm{bp}$, in which a tripartite exonintron structure (three exons and two introns) exists (Fig. 2B). Exons 1, 2, and 3 are composed of 25, 66, and $92 \mathrm{bp}$, respectively. The end of the nuclear intron is in accordance with the GT-AG rule, the splice acceptor/donor consensus sequences. ${ }^{8)}$ The $3^{\prime}$ untranslated regions ( $3^{\prime}$-UTRs) of nucleotide sequences identified by $3^{\prime}$-RACE carry the AATAAA polyadenylation signal 18 bp upstream from the starting region of the poly(A) tail (Fig. 2C). Figure $2 \mathrm{C}$ also shows the MT cDNA sequences and predicted amino acids. The length of the open reading frame is $183 \mathrm{bp}$ and it encodes a polypeptide of 60 amino acids containing six Cys-X-Cys motifs, typically found in this protein family. The crucian carp MT protein shows typical MT patterns, such as a lack of aromatic residues and presence of six gylcine residues. ${ }^{21)}$ In the majority of vertebrates, two major isoforms of MT that can be resolved by ion exchange chromatography are found (designated MT-I and MT-II) and these are encoded by two coordinately regulated genes lying about $6 \mathrm{~kb}$ apart on the same chromosome. ${ }^{22)}$ In many fish species, including the crucian carp, only one isoform appears to be present ${ }^{23,24)}$ and synthesis is transcriptionally regulated by metals such cadmium. ${ }^{25,26)}$ Recently, the Japanese crucian carp (Carassius cuvieri, C. cuvieri) has been reported to synthesize two major isoforms of MT (ccMT-1 and ccMT-2) in the liver and kidney by several inducers including air-pumping stress, dexamethasone, and metals. ${ }^{18,19)}$ 
(A)

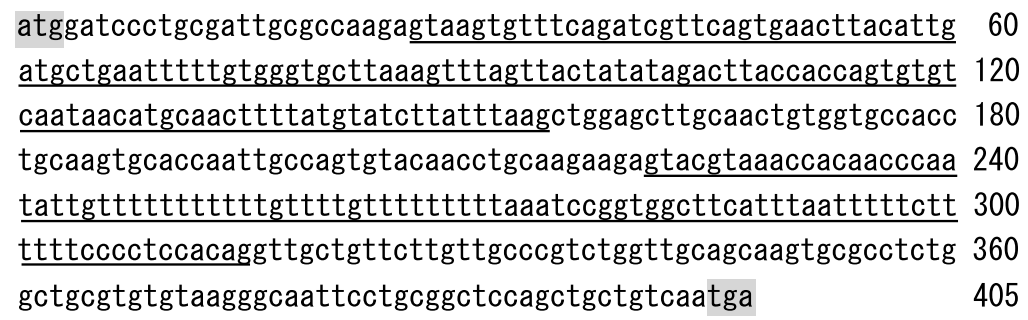

(B)

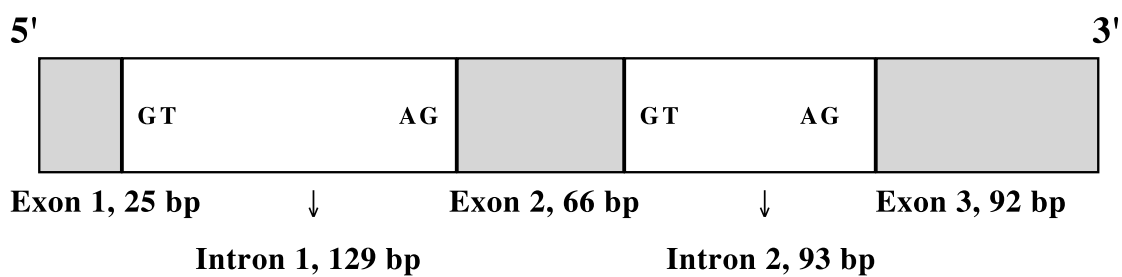

(C)

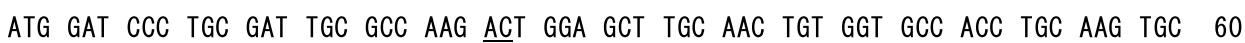

$\begin{array}{lllllllllllllllllllllllllllllll}M & D & P & C & D & C & A & K & T & G & A & C & N & C & G & A & T & C & K & C\end{array}$

ACC AAT TGC CAG TGT ACA ACC TGC AAG AAG AGT TGC TGT TCT TGT TGC CCG TCT GGT TGC 120

$\begin{array}{llllllllllllllllllll}\mathrm{T} & \mathrm{N} & \mathrm{C} & \mathrm{Q} & \mathrm{C} & \mathrm{T} & \mathrm{T} & \mathrm{C} & \mathrm{K} & \mathrm{K} & \mathrm{S} & \mathrm{C} & \mathrm{C} & \mathrm{S} & \mathrm{C} & \mathrm{C} & \mathrm{P} & \mathrm{S} & \mathrm{G} & \mathrm{C}\end{array}$

AGC AAG TGC GCC TCT GGC TGC GTG TGT AAG GGC AAT TCC TGC GGC TCC AGC TGC TGT CAA 180

$\begin{array}{lllllllllllllllllllllllllllllllllll}S & K & C & A & S & G & C & V & C & K & G & N & S & C & G & S & S & C & C & Q\end{array}$

TGA GGA GGT CAA CGT GAT GTT TTG TTA CAA CAA TGT GAA CTT GTT CGT CTG TGC TAG GCG 240

TCT TCG CTT TTC CAT CGC ATG AAT GTT TTA TTT TTA CAT GAT TCT AAT AAA CGA CCT CCC 300

TGT TGT TCT AAA AAA AAA

318

Fig. 2. Sequence of Exons and Introns in $\mathrm{MT} \operatorname{gDNA}(\mathrm{A}, \mathrm{B})$ and Nucleotide and Deduced Amino Acid Sequences of MT cDNA (C) in Crucian Carp C. auratus

Underlined sequences belong to introns (A). MT gene is composed of three exons and two introns. Exons 1, 2, and 3 are composed of 25, 66, and $92 \mathrm{bp}$, respectively (B). The length of the open reading frame is $183 \mathrm{bp}$ and it encodes a polypeptide of 60 amino acids containing six Cys-X-Cys motifs that are shown in the shaded boxes. The splicing points are underlined and the consensus sequence for polyadenylation is shown in the box (C).

The cDNA sequence and deduced amino acid sequence were compared with those of the published sequences using the NCBI BLAST search program. It revealed significant similarity with Cyprinus carpio (C. carpio) and Danio rerio (D. rerio) (zebrafish) MT (Table 1). Comparison of the putative MT protein with other sequences available in the GenBank database revealed $100 \%$ identity with zebrafish, $95 \%$ with goldfish, $96.7 \%$ with common carp MTI, 98.3\% with common carp MTII, 98.3\% with crucian carp MT-A, $95 \%$ with crucian carp MT-
B, $95 \%$ with stone loach, and $95.9 \%$ with chub (Fig. 3).

\section{Induction of MT mRNA and Cadmium Accumu- lation in Gills}

In general, high levels of MT protein are correlated with high levels of MT mRNA. ${ }^{27)}$ When animals are exposed to cadmium, they synthesize detoxifying proteins such as MT. However, prior studies on fish MT as a bioindicator of aquatic metal pollution are few and with diverse results. In this 
Table 1. Comparison of MT cDNA Sequences in Fish Species

\begin{tabular}{lcc}
\hline \hline Fish & Size (bp) & Similarity(\%) \\
\hline Zebrafish (Danio rerio) & 309 & $302 / 309$ \\
Goldfish (Carassius auratus) & 312 & $297 / 312$ \\
Common carp (Cyprinus carpio) MTI & 372 & $246 / 271$ \\
Common carp (Cyprinus carpio) MTII & 240 & $223 / 253$ \\
Crucian carp (Carasius cuvieri) MT-A & 339 & $295 / 307$ \\
Crucian carp (Carasius cuvieri) MT-B & 503 & $256 / 282$ \\
Stone loach (Noemacheilus barbatulus) & 276 & $156 / 170$ \\
Chub (Leucisus cephalus) & 148 & $138 / 148$ \\
\hline \multicolumn{2}{c}{ MT cDNA sequences were compared with the published sequences of the genes using }
\end{tabular}
the NCBI BLAST search program.

$\begin{array}{llll}\text { Carassius auratus } & 1 \text { MDPCDCAKTGACNCGATCKCTNCQCTTCKKSCCSCCPSGCSKCASGCVCKGNSCGSSCCQ } & 60 \\ \text { Zebra fish } & 1 \text { MDPCDCAKTGACNCGATCKCTNCQCTTCKKSCCSCCPSGCSKCASGCVCKGNSCGSSCCQ } & 60 \\ \text { Goldfish } & 1 \text { MDPCECAKTGACNCGATCKCTNCQCTTCKKSCCFCCPSGCSKCASGCVCNGNSCGSSCCQ } & 60 \\ \text { Common carp I } & 1 \text { MDPCDCAKTGTCNCGATCKCTNCQCKTCKKSCCSCCPSGCSKCASGCVCKGNSCGSSCCQ } & 60 \\ \text { Common carpII } & 1 \text { MDPCDCAKTGTCNCGATCKCTNCQCTTCKKSCCSCCPSGCSKCASGCVCKGNSCGSSCCQ } & 60 \\ \text { Crucian carp MT-A } & 1 \text { MDPCDCAKTGPCNCGATCKCTNCQCTTCKKSCCSCCPSGCSKCASGCVCKGNSCGSSCCQ } & 60 \\ \text { Crucian carp MT-B } & 1 \text { MDPCDCAKTGACNCGATCKCTNCQCKTCKKSCCPCCPSGCSKCASGCVCKDNSCGSSCCQ } & 60 \\ \text { Loach } & 1 \text { MDPCDCSKTGTCNCGATCKCTNCQCTTCKKSCCSCCPSGCSKCASGCVCKGNSCDSSCCQ } & 60 \\ \text { Chub } & 7 & \text { AKTGTCNCGATCKCTNCQCTTCKKSCCTCCPSGCSKCASGCVCKGNSCG } & 55\end{array}$

Fig. 3. Crucian Carp C. auratus MT Aligned with MT from Other Fish Species

The GenBank accession numbers of the proteins are as follows: zebrafish D. rerio MT (NP571150), goldfish C. auratus MT (JC2419), common carp C. carpio MT I (Q91910), common carp C. carpio MT II (O13269), crucian carp C. cuvieri MT-A (AY165047), crucian carp C. cuvieri MT-B (AY165048), stone loach B. barbatulus MT (P25128), and chub L. cephalus (AAK31301). The highlighted letters in the shaded boxes in the sequence show the different amino acids between MT of $C$. auratus and of other fish species according to the alignment.

study, crucian carp were exposed to cadmium $0,0.01$, 0.1 , and $0.5 \mathrm{mg} / \mathrm{l}$ for 25 days to measure the induction level of MT mRNA in the gills and the induction was compared with cadmium accumulation to evaluate application of mRNA induction as a possible biomarker of cadmium contamination. Our previous results showed that the induction of mRNA in the gills is more sensitive than in any other tissues such as the liver, kidney, and fins (data not shown). The gills were thus chosen as the target organ.

Electrophoretic analysis of MT mRNA in the gills after cadmium exposure $(0.5 \mathrm{mg} / \mathrm{l})$ shows the induction of mRNA during the exposure period but the induction was not time-dependent. It diminished after a 1-day exposure (Fig. 4A). When the MT mRNA level in the gills was compared with cadmium accumulation after varying doses of cadmium for 25 days, the induction of MT mRNA was not correlated with cadmium accumulation in the gills. MT mRNA level was increased rapidly after a 1-day of exposure and then decreased even though cadmium accumulation was increased (Fig. 4B). We do not know the exact meaning of this phenomenon but the decrease in MT may be related to the toxicity to the fish in long-term cadmium exposure.

In previous reports in catfish, ${ }^{28)}$ plaice, ${ }^{25)}$ and rat liver, ${ }^{29)}$ induction of MT synthesis was not linearly related to cadmium dosage in either the liver or kidney when measured shortly after cadmium injection. De Smet et al. explained that in comparison with control common carp (C. carpio) (Cd, Zn)-MT concentrations increased up to 4.5 -fold in the kidney and two-fold in the gills during cadmium exposure of 29 days. ${ }^{30)}$ Although cadmium clearly leads to $d e$ novo synthesis, the role of this protein in the detoxification process is clearly organ specific and its synthesis does not correlate with cadmium accumulation. Huang proposed that the initial effect of nonspecific cadmium-binding to intracellular ligands (proteins) can be regarded as a toxic interaction and that detoxification of cadmium by MT was by trans- 
(A)

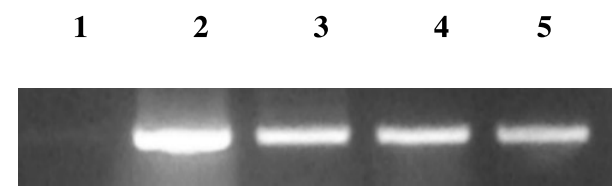

(B)

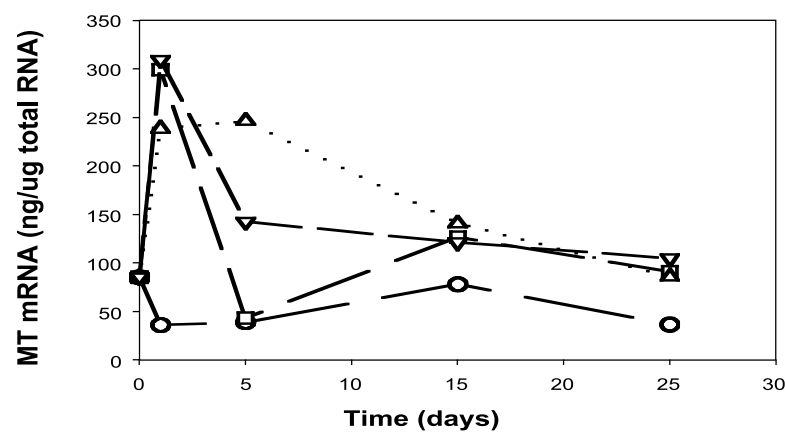

(C)

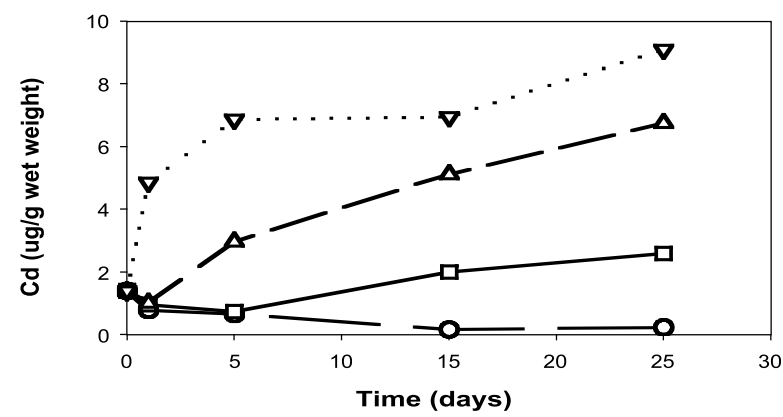

Fig. 4. Expression of MT mRNA and Cadmium Accumulation in Gills

Time-course of MT mRNA expressions is shown in $0.5 \mathrm{mg} / \mathrm{l}$-treated C. auratus. Fish were killed on day 1 (lane 2), day 5 (lane 3), day 15 (lane 4), and day 25 (lane 5), respectively, and mRNA expression of control fish is shown in lane 1 (A). Expression of MT mRNA and cadmium accumulation in the gills after exposure to varying cadmium concentration for 25 days are shown in panel B and panel C, respectively. Three fish from each treated group were killed 1, 5, 15, and 25 days after cadmium exposure and the mean values of each point are represented. MT mRNA was determined by RT-PCR and total RNA $1 \mu \mathrm{g}$ was subjected to the RT-PCR reaction. The expression level was determined using densitometer, and the unit is expressed as $\mathrm{ng} / \mu \mathrm{g}$ total RNA. Cadmium accumulation was measured by atomic absorption. $\bigcirc$, control; $\square, 0.01 \mathrm{mg} / 1 ; \triangle, 0.1 \mathrm{mg} / \mathrm{l} ; \nabla, 0.5 \mathrm{mg} / \mathrm{l}$.

fer of cadmium to newly synthesized MT, that is, it is a "rescue" phenomenon. ${ }^{31)}$ Therefore there will be a progressive inhibition of cellular processes including MT mRNA transcription with increasing concentrations of cadmium. The data in this study, which did not show a time-dependent increase in
MT mRNA, support such a proposal and suggest that MT mRNA induction may have limitations as a biomarker of metal contamination of aquatic environments.

\section{REFERENCES}

1) Hylland, K., Haux, C. and Hogstrand, C. (1992) Hepatic metallothionein and heavy metals in dab Limanda limanda from the German Bight. Mar. Ecol. Prog. Ser., 91, 89-96.

2) Overnell, J. and Abdullah, M. I. (1988) Metallothionein and metal levels in flounder Platichthys flesus from four field sites and in flounder dosed with waterborne copper. Mar. Ecol. Prog. Ser., 46, 71-74.

3) Roch, M., McCarter, J. A., Matheson, A. T., Clark, M. and Olafson, R. W. (1982) Hepatic metallothionein in rainbow trout (Salmo gairdneri) as an indicator of metal pollution in the Campbell River System. Can. J. Fish. Aquat. Sci., 39, 1596-1601.

4) Hamer, D. (1987) Metallothionein. Ann. Rev. Biochem., 55, 913-951.

5) Stagg, R., Goksoyr, A. and Rodger, G. (1992) Changes in branchial $\mathrm{Na}^{+}, \mathrm{K}^{+}$-ATPase, metallothionein and P450 1A1 in dab Limanda limanda in the German Bight: Indicators of sediment contamination. Mar. Ecol. Prog. Ser., 91, 105-115.

6) Sulaiman, N., George, S. and Burke, M. D. (1991) Assessment of sublethal pollutant impact on flounders in an inductrialised estuary using hepatic biochemical indices. Mar. Ecol. Prog. Ser., 68, $207-$ 212.

7) Das, B. K. and Kaviraj, A. (1994) Influence of potassium permanganate, cobalt chloride, and dietary supplement of vitamin B complex on the histopathological changes in gill epithelium of common carp exposed to cadmium. Progressive Fish-Culturist, 56, 265-268.

8) Breathnach, R. and Chambon, P. (1981) Organization and expression of eukaryotic split genes coding for protein. Ann. Rev. Biochem., 50, 349-383.

9) Lee, C., Na, J. G., Lee, K. C. and Park, K. (2002) Choriogenin mRNA induction in male medaka, Oryzias latipes as a biomarker of endocrine disruption. Aquat. Toxicol., 61, 233-241.

10) Ryu, J., Lee, M. S., Na, J. G., Chung, K., Song, B. J. and Park, K. (2004) Molecular cloning of cytochrome P4501A cDNA of medaka (Oryzias latipes) and messenger ribonucleic acid regulation by environment pollutants. Environ. Toxicol. Chem., 23, 1004-1011.

11) Lee, C., Jeon, S. H., Na, J. G. and Park, K. (2003) 
Sequence analysis of choriogenin $\mathrm{H}$ gene of medaka (Oryzias latipes) and mRNA expression. Environ. Toxicol. Chem., 21, 1709-1714.

12) Lee, C., Jeon, S. H., Na, J. G., Choi, Y. J. and Park, K. (2002) Sensitivities of mRNA expression of vitellogenin and estrogen receptor by estrogenic chemicals in medaka, Oryzias latipes. J. Health Sci., 48, 441-445.

13) Barak, N. A. E. and Mason, C. F. (1990) Mecury, cadmium and lead concentrations in five species of freshwater fish from Eastern England. Sci. Total Environ., 92, 257-263.

14) Dethloff, G. M., Schlenk, D., Hamm, J. T. and Bailey, H. C. (1999) Alterations in physiological parameters of rainbow trout (Oncorhynchus mykiss) with exposure to copper and copper/zinc mixtures. Ecotoxicol. Environ. Saf., 42, 253-264.

15) Chan, K. M. (1994) PCR-cloning of goldfish and tilapia metallothionein complementary DNAs. Biochem. Biophys. Res. Commun., 205, 368-374.

16) George, S., Wright, J., Carpene, E. and Kindt, M. (2000) Kinetics and magnitude of metallothionein induction by $\mathrm{Cd}, \mathrm{Cu}, \mathrm{Hg}$ and $\mathrm{Zn}$ in European flounder for environmental monitoring. Mar. Environ. Res., 50, 433-434.

17) Hermesz, E., Gazdag, A. P., Ali, K. S., Nemcsok, K. and Abraham, M. (2002) Differential regulation of the two metallothionein genes in common carp. Acta Biol. Hung., 53, 343-350.

18) Muto, N., Hong-Wei, R., Gab-Soo, H., Shinpei, T., Norio, I. and Keiichi, T. (1999) Induction of two major isoforms of metallothionein in crucian carp (Carassius cuvieri) by air-pumping stress, dexamethasone, and metals. Comp. Biochem. Physiol., C112, 75-82.

19) Ren, H. W., Norio, I., Masako, K., Shinpei, T., Junya, K., Gab-Soo, H., Tsuyoshi, N., Norio, M. and Keiichi, T. (2000) Two metallothioneins in the freshwater fish, crucian carp (Carassius cuvieri): cDNA cloning and assignment of their expression isoforms. Biol. Pharm. Bull., 23, 145-148.

20) Kowk, L. L., Po, W. K., Judy, K. Y. W. and King, M. C. (1998) Metal toxicity and metallothionein gene expression studies in common carp and tilapia. Mar. Environ. Res., 46, 563-566.

21) Nadia, C., Francesco, D., Jan-Willem, van de L., Bruno, B. and Aldo, V. (2002) Cloning and sequencing of novel metallothionein gene in Mytilus galloprovincialis Lam. Comp. Biochem. Physiol., 131, 217-222.

22) Searle, P. F., Davison, B. L., Stuart, G. W., Wilkie, T. M., Norstedt, G. and Palmiter, R. D. (1984) Regulation, linkage and sequence of the mouse metallothionein I and II genes. Mol. Cell. Biol., 4, 1221-1230.

23) George, S., Burgess, D., Leaver, M. and Frerichs, N. (1992) Metallothionein induction in cultured fibroblasts and liver of a marine flatfish, the turbot, Scophthalmus maximus. Fish Physiol. Biochem., 10, 43-54.

24) George, S. and Olsson, P. E. (1994) Metallothioneins as indicators of trace metal pollution. In Biomonitoring of Coastal Waters and Estuaries (Kramer, K. J. M., Ed.), CRC Press, Boca Raton, pp. 151-171.

25) George, S. (1989) Cadmium effect on plaice liver xenobiotic and metal detoxification systems: doseresponse. Aquat. Toxicol., 15, 303-310.

26) Zafarullah, M., Olsson, P. E. and Gedamu, L. (1989) Endogenous and heavy metal-ion-induced metallothionein gene expression in salmonid tissues and cell lines. Gene, 83, 85-93.

27) Rosaria, S., Vincenzo, C., Marilisa, R., Clemente, C., Antonio, C., Peter, K., Guido, D. P. and Elio, P. (1997) Difference in hepatic metallothionein content in Antarctic red-blooded and haemoglobinless fish: undetectable metallothionein levels in haemoglobinless fish is accompanied by accumulation of untranslated metallothionein mRNA. Biochem. J., 322, 207-211.

28) Chattergee, A. and Maiti, I. B. (1991) Induction and turnover of catfish (Heteropneustes fossilis) metallothionein. Mol. Cell. Biochem., 108, 29-38.

29) Yoshikawa, H. and Ohta, P. E. (1982) Biological Role of Metallothionein (Foulkes, F. C., Ed.), Elsevier, New York, pp. 11-23.

30) De Smet, H., De Wachter, B., Lobinski, R. and Blust, R. (2001) Dynamics of ( $\mathrm{Cd}, \mathrm{Zn})$-metallothionein in gills, liver and kidney of common carp Cyprinus carpio during cadmium exposure. Aquat. Toxicol., 52, 269-281.

31) Huang, P. C. (1993) Metallothionein structure/function interface. In Metallothionein III: Biological Roles and Medical Implications (Sizuki, K. T., Imura, N. and Kimura, M., Eds.), Birkhauser Verlag, Basel, pp. 407-426. 